\title{
ANXIOUS NATIONALS AND OTHERS: THE NATION'S UNWANTED-A DISCOURSE ON HOMI BHABHA, PAUL GILROY AND AMBALAVANAR SIVANANDAN
}

Homi Bhabha, Paul Gilroy, and A. Sivanandan examine anxieties of the nation in their respective texts, each adding perspective to the much discussed discourse of the national selves and the non-national Others. While for Bhabha, his anxiety lies in the time lag between the present and its invented anteriority as he looks back at national "past," Gilroy re-writes narratives of modernity in the slave's perspective, subverting the masterdiscourse written by the anxious Self who seeks to overcome its anxiety by the constant oppression and suppression of the Other. Sivanandan looks back at a "past" re-written by the subaltern, and cannot but kill memories of violence in his Janus-faced narrative, anxiously seeking a "fictitious space of [an alternative] future" (Bhabha, "Anxious Nations and Nervous States" 202). For all three, neither can this multifaceted analysis of the anxieties of the national Self in the face of the non-national Other be easily resolved nor can it be done away with, for the mere reason that despite the anxieties brought upon the Self by the nation's Unwanted, it is the very presence of the non-national Other that consolidates the national Self.

Sivanandan's look back is as anxious as that of Bhabha's and as subversive as that of Gilroy's slave texts albeit for different reasons. If for Bhabha, the "dangers implicit on/in the threshold of [national] identity" are its encounters with the "unchosen", the marginalized, or the peripheralized non-people of the nation's democracy," ("Anxious Nations and Nervous States" 207) for Sivanandan, it is precisely in the perspective of these non-people that national narratives need to be re-written. If for Gilroy, mainstream texts of the modern nation need to be drastically re-thought, for Sivanandan, that rethinking (which he undertakes in his text) needs in turn to undergo a second level of subversion. Thus, his anxiety lies in the necessity to re-write When Memory Dies' already re-written "past," in order to open space for at least the possibility of an alternative, non-violent, hybridized "future". What is to be noted here is that, though the foci of the three authors are both

\footnotetext{
${ }^{1}$ The terms "past" and "future" will be consistently placed within inverted commas in order to mark their inventedness in relation to the present.
} 
different yet at the same time intersecting, they indubitably agree on the inventedness of the "past," the recognition of which makes available to them the potential for changing not only the "past" but also the "future." If the "past" is recognized as an invented temporality, then so is it possible to invent change where change is said to be impossible.

Likewise, Gilroy comments (in his "Masters, Mistresses, Slaves, and the Antinomies of Modernity") as follows, on the apparent unviability of change, that is occasioned by the very absence of the histories of the "past's" Unwanted. The argument develops on the logic that if there are no slave histories, then there can be no discussion on how the slave histories can be changed:

[...I]nterest in the social and the political subordination of blacks and other non-European peoples does not generally feature in contemporary debates around the philosophical, ideological, or cultural content and consequences of modernity. Instead an innocent modernity emerges from the apparently happy social relations $[\ldots]$ readily purged of any traces of the people without history whose degraded lives might raise awkward questions about the limits of bourgeois humanism (44; emphasis added).

The black slaves or the "people without history" were ahistorical in the sense that the unpleasant memories of their squalid existence were either to be forgotten or to be violently wiped out within the mainstream narratives of modernity, in an attempt to glorify the virtues of bourgeois humanism. These "degraded lives" considered "humanism's Other," in this very identification of absence-presence, makes one question the legitimacy of the modern sense of justice.

On a similar note, Sivanandan, too, has reservations about the apparently unified, innocent nation which conveniently forgets to include in its fold, subaltern, in that sense, non-national narratives. In writing his work in the perspective of the Podi Appus, the Wijepalas, the labourers and the much clichéd 'poor and the downtrodden,' he initially sets out to sanitize the tale of the elite, glamour figures of the Goonesinhas who compromise on independence, and of the Roys whose red kerchiefs are of satin or at least of the best cotton. As it is, it is timely "for the primal history of modernity to be reconstructed from the slave's point of view" (Gilroy 55). As it is, it is time to reconceptualize the nation, where the nation's anxiety generated by the presence of the Unwanted, may turn into a jubilation of heterogeneous hybridity. 
Such subaltern narratives (here taken in the sense of narratives that are written in a subaltern perspective rather than narratives that play the role of the subaltern, for in "speaking", they are no longer the subaltern) question the illusory homogeneity of the nation's "past" from which the present seeks to assure itself a nationalist "future". Bhabha sees this illusory homogeneity as a product of the present's invention of the "past" (a "past" that is invented by the mainstream agents of production such as the elite); a striking parallel of this is found in Gilroy where he talks of the "cultural activists [who] even now engage in 'rescuing critiques' of the present by both mobilizing memories of the past and inventing an imaginary past-ness that can fuel their utopian hopes" (57). And "it is from those traditions of political thought and literary language that the nation emerges as a powerful historical idea in the west" (Bhabha, Nation and Narration 1).

This power, in turn, rests on its dependence on a time formation which gains its legitimacy only in relation to the present; a phenomenon that constantly needs to pronounce/articulate itself in order to secure itself a sense of continuity. This is then why, the relation between the present ("today") and the "past" ("yesterday") is one of mutual dependence, where each formation has a relative presence; the present is required to assert its "nowness" in relation to a temporality that is "before now," while the "past" cannot be "yesterday" without the parallel existence of a "today," the point of time from which the former steps back. Stepping back cannot be carried out in a vacuum, since there underlies the suggestion that one steps back from a certain point, and on that point rests the integrity of the motion that follows. The nation then, cannot hold itself together singularly within the time dimension of "today"/"now" which is constantly in flux. If at all stability is sought, a momentary pause can only be found in a "past" that can be invented and held on to for all its worth. However, what eventually proves to be disappointing is the unavoidable presence of historical (or ahistorical?) subversive figures, who, contrary to the aspirations of national unification, only leave the nation threatened with dissolution. Therefore, the Unwanted is either to be unpronounced/unarticulated, producing an apparent absence of the Other, or it is to be pushed into the category of national-threat that is to be eliminated for the betterment of the national subject.

Thus, the nation, much theorized on and the eternally evasive, cannot but be anxious in its ephemeralty, for in order to consolidate itself, it needs to rely on an equally ephemeral "past" that embodies the risk of the unwelcome presence of the nation's Other. In a sense, the desire for a "past," coupling with the desire for "roots" generate the desire to invent the national "past". However, since both concepts of national "past" and "future" are 
equally ephemeral, (since they come into being only in their relation to the present) neither has an essentialized being. Then, this non-essential reality (?) needs, at the least, to assume an apparent essentiality, a sense of "naturalness" in order to produce the beautiful lies which make the modern national man and woman feel that they truly belong. The very fact that the item Nationality naturally figures amongst the other seemingly natural categories of the Curriculum Vitae (CV, which I would expand as "Categories of Modern Vacuity"; the categories are full of constructed meaning but at the same time, they are empty of any essentiality), clearly illustrates its endowed sense of the unchosen:

\title{
Categories of Modern Vacuity
}

\author{
Name in full: Gayathri Madhurangi Hewagama \\ Date of birth: $18^{\text {th }}$ June 1984 \\ Age: 27 \\ Sex: Female \\ Nationality: Sri Lankan \\ Religion: Buddhism [...]
}

The particular ease and the naturalness with which "I" ("I" here, used to refer to the national subject) was able to fill in the information required, makes a statement of its own. Each item in the CV associates with it a sense of the unchosen, thus the natural. My nationality is expected to be as natural as my gender/sex, (which, yet again are constructs in themselves) which would generate an instinctive respect for the nation. "I" shall, as a citizen of the Sri Lankan nation, instinctively love my country. If "I" were to forget my national anthem, "I" shall most justly be considered unpatriotic. In other words, "l" may not be too sure of what "my nation" is, yet, "I" am expected to respect "it".

Nation-building then relies exclusively on the idea of unification. It is precisely this totalizing wholeness of the notion of People-As-One that seeks to ignore the multiple modalities of the modern condition. The suggestion that "an all-encompassing modernity affects everyone in a uniform and an essentially sinilar way," in fact, "runs contrary to [Gilroy's] concern with the variations and discontinuities in modern experience and with the decentered and inescapably plural nature of modern subjectivity and identity" (Gilroy 46). 
This disavowal of difference is also a disavowal of the presence of the potent Other, which leaves the Self with a profound sense of discomfort. In fact, the state of illusion in which the Self finds consolation, rests on a belief that by simply ignoring the potency of the Other, what poses the greatest threat to the Self's integrity can be overcome. This is then why, the modern nation that pampers itself with the illusory notion of unity and homogeneity cannot but become anxious in its backward glance, when the long ignored racial, ethnic, classed and gendered Other (going by the generalizations of figures like the 'black slave', the 'underprivileged minority group member', 'the proletarian', or 'the woman oppressed by patriarchy') confront the present with a previously undisclosed audacity.

This anxiety produces ambivalence when such agents of dissolution (the earlier subversive figures who gain agency by their very Otherness) meet with the loosely-held notion of the Nation-As-One; both the present as well as the "past" are internally disjointed, though the latter may seem not to be so. Then, even if by turning away from a heterogeneous present one seeks for a homogenous national "past," one finds merely a make-believe homogeneity. Thus, the notion of the People-As-One falls apart when the unchosen dissolves this apparent national unification. Nationness no longer seems to be natural when the possibility of the non-national Other, in the form of divisive bodies such as racial and ethnic groups emerge, fragmenting national unity. If the "quest for identity cannot be separated from the experience of division," (Bhabha, "Anxious Nations and Nervous States 202) the quest for national identity cannot then be separated from the experience of racial, ethnic, class and gender division.

Sivanandan's look back initially exposes such divisive experience out of which a different/better "future" is sought. This "future" is not one that lives in the illusory luxury of an absolutely unified cosmos, (is unification a luxury?) but one that simultaneously accommodates unification in hybridity (not 'unification of hybridity' which in a sense marks a disavowal of differences). When Memory Dies in fact traces the trajectory from a less divisive "past" to a more divisive present where multiple forces instigate its final episodes of violence; Book One depicts a comparatively unified oneness between the ethnicities, Book Two marks the gradual widening of the ethnic gap, while Book Three sees tensions between sociopolitical divisions as ending in suffering and eventual death.

At the closing pages of the book, the resonances of the title of Sivanandan's novel appeal to the reader to perhaps even re-write the narrative s/he had so far read, aspiring for an alternative, less-violent (or non-violent) "future". However, it should not be grasped as 
simply an invitation to demolish the text that runs through four-hundred and eleven pages and spans across three Books. The appeal is more complex than an invitation to a facile denarrativizing criticism. Instead, it is about primarily the writing of a text in a perspective that is considered subaltern, and secondly of the de-writing of this laboriously produced narrative in order to perhaps create "false" memories. The nation's anxiety in including such subaltern narratives in the pages of its national history, is exploited to a great extent here, where it is not the presence of the subalterns that make Sivanandan anxious but the violence prevalent in their midst. This is then why he feels the need for the generation of "false" memories which are if not devoid of violence, are at least less submerged in negativity. These "false" memories, which are to be less violent than those of the nation's "past", are in turn expected to pave the way to a less violent national "future".

Thereafter, in their subaltern narrativizations of national memory, both Sivanandan and Gilroy invert the relationship between the lord and the bondsman in absolute contrast to Hegel's conception of it. If the Hegelian slave prefers life under his bondsman despite the abject conditions of the plantation, Gilroy's seeks death. Garner slaughters her children in the form of an "emancipatory assault" (Gilroy 66) while her mother-in-law passively looks on. The suicide of the slave not only marks resistance in the form of lost property, but it also leaves the slave-bondsman binary in a certain void by taking away the Other, in relation to which the bondsman constructs his Self. Sivanandan's inversion lies on his version of the so-called ethnic conflict which is written in (what he understands as) the perspective of the Tamils and the non-elite socialist activists. By thus subverting the mainstream elite Sinhalese narratives of the times, he stands out as one who contributes in his own way, to the painting of a more politically balanced national canvas. For instance, $\mathrm{SW}$, (Mr.Wijepala, the political activist who works to better the conditions of the local labourers) continuously emphasizes the necessity to write the narrative of social struggle in the subaltern perspective. Podi Appus are considered more important than the great elite leaders (figures like Goonesinha, in whose names statues and villages are built). The narrative of social struggle is, therefore, for both Sivanandan and his fictional character, not an epic but a folk tale (When Memory Dies 55).

Likewise, Gilroy's re-narrativization of modernity calls upon authors such as Frederick Douglass and their texts which "present a range of important black perspectives on the problem of modernity" (Gilroy 58). Further, the "past" that the Black Atlantic creates is a "personal history" (Gilroy 69), which negates the conventional European code of rationality, and traditional expectations of historiography (such as the requirements of 
objective analysis, collection of fact, chronology etc). The narrative that the Black Atlantic invents/writes is different from (or is a different version of) the prevalent histories of modernity. It is, in fact, a counter narrative; autobiographies of black activists, which (according to Western patterns of thought) usually fall under conventionally subjective genre, perform an emancipatory role in their act of subverting the expectations of objectivity. Music, dance and art forms which were seen by the Enlightened as offering no scope for political activism, were put into use by the plantation slaves in such a manner that they subverted the politics of the master-slave binary. Such subversive measures taken together constructed a human fabric that celebrated its differences, not merely in terms of its different hue but also in terns of the multiple patterns that ran across its surface.

Thus, "[Gilroy] intend[s] not only to question the credibility of a tidy, holistic conception of modernity" which ignores the beauty of the multiple patterns on the fabric, "but also to argue for the inversion of the relationship between margin and center as it has appeared within the master discourses of the master race" (45). Sivanandan's is as redemptive as Gilroy's narrative, which however is to be eventually deconstructed to serve the purposes of what he understands as harmonious hybridity. Narratives of figures that are conventionally identified as subaltern merge in the attempt to recreate a "past" anew, which finally calls for an emancipatory dissolution of the previous histories on Tamil-Sinhalese ethnic violence, leaving space for a peaceful "future" for the forthcoming generations. Thus, in the simultaneous look back and look forward of the novel there is a double anxiety, in so far that for Sivanandan's nation not only the presence of the Unwanted but also the need for the creation of less/nonviolent memories of the Unwanted become a double burden. The author does not find redemption in the mere inclusion of the nation's Other in his narrative, but he does so through a far more crucial measure of overcoming one's violent "past" in order to save one's "future."

Then, no longer is the nation a unifying and homogenous phenomenon, both its "past" and "future" shifting in kaleidoscopic patterns. It is in avoiding such instability that the modern citizen longs to seek comfort in a seemingly unified nation, which would attribute a sense of legitimacy to his/her identity. However, roots, the aforementioned source of a legitimate foundation (a beginning from where one can go on), where one belongs, defeat themselves when they are uprooted by the presence of the divisive Other. On a similar note, When Memory Dies is also about roots-root causes of the ethnic conflict and also of the constructive roots of four generations represented by Pandyan, 
Sahadevan, Rajan and Vijay, and finally of their violent uprooting, the memories of which need to be set aside for the sake of a peaceful hereafter.

Pandyan, a representative figure of the old system (with whom the novel begins), sees his land-centered life-style breaking down as the British Raj constructs a new system that designates a government job the only "proper job" to be desired. Surely the British, by putting the English-speaking Tamils at an advantage over both Tamil and Sinhalese nonspeakers of English, create a rift between an English-speaking class as opposed to a nonEnglish-speaking class? Saha, who moves out of the old world of his father and is in turn welcomed by the new, becomes a vehicle through which a new kind of security and respect is garnered. The kind of social-change that is taking place at this point of time cannot but disclose the unraveling.of a different kind of "future", which is not a "future" that is in the form of a logical evolution of the present state of conditions, but a wholly novel and an even unfamiliar hereafter. However, in this look forward, at least Pandyan is not anxious:

Now the land had been taken from him. His rhythm was broken. Time had become one-dimensional, unilinear. He was at outs with the world.

But with his son he found another rhythm, a way of keeping step with the new order of things, another measure of time. It was not altogether to his liking, but as he saw this outer seed sprout and grow and battle with its own world, he determined to keep faith with it. [...] In the certainty of that continuity. Pandyan rose from his bed and walked tall in the promise of Sahadevan's days, wearing now a verti and shawl, as a father of a prospective government servant should, and sporting a rolledgold wrist watch. (When Memory Dies 11)

The socio-political relations between the two ethnicities are comparatively less convoluted in Book One, since they are pushed backstage by the larger issues associated with colonialism at the time. (At this point, the more crucial issue is Sri Lanka's gaining independence from the British Raj). Meanwhile Tamils and Sinhalese apparently coexist in a sense of harmony, in spite of trivial mismatches. At least initially, it is merely a matter of the difference of food habits, or the comfort-discomfort divide between the South and the North, that seem to add minor tensions to an otherwise peaceful state of affairs. The kind of relationship between Saha and Tissa, Saha and Tissa's parents, Saha and Tissa's uncle and aunt, (SW and Prema) cannot but present the reader with (a prototype of) an almost perfect 
bond between the two ethnicities. The friendship between Saha and Tissa is one of loyalty and it is also mutually beneficial. Saha, on the one hand, becomes instrumental in trying to bring SW and Tissa together, while constantly reminding the latter of his duty to his family. Tissa, on the other hand, contributes to the process of making Saha more nationally aware, while constantly reminding him of his public duty. Prema is almost a surrogate mother to Saha, while SW figures as the mainspring of Saha's socialist education, where the former greatly influences the character formation of the latter, as conventionally a father would his son.

However, one may feel that Sivanandan overdoes the healthy relations between the Tamils and the Sinhalese at this point. Perhaps, in order to balance the portrayal as it were, he inserts certain minor characters and particular references to ethnic tensions at different points of Book One. Even SW, who initially comes out as one who ardently believes in a greater humanity which transcends socially-constructed divisions, raises his eyebrows when he gets to know that his nephew Tissa wants to marry a Muslim; "An affair with a Muslim girl though, was another matter, especially if she was poor and proud and her family opposed to it" (When Memory Dies 45). Thus, Book One ends with a certain sense of failure; the anti-colonial project leaves one feeling betrayed, and the relations between the Sinhalese and the Tamils slowly but steadily deteriorate. The divide-and-rule policy of the British (in their creation of different classes and the setting of one against the other) cannot but contribute largely to this ever widening gap between the ethnicities.

Book Two starts with Hopkins' line, "Mine, $O$ thou lord of life, send my roots rain." This is contrasted with Sivanandan's modification of it: "My Roots No Rain". Does this then suggest that Rajan's roots are malnourished; that his roots are at the risk of withering away? From the very outset we realise that Rajan's life is more complex than his forefathers' (Pandyan's and Saha's). Pandyan and his wife constitute a traditional espousal which generates a sense of familial stability and a loyalty towards one's family in Saha, their offspring. Moreover, it is a marriage between a man and a woman who belong to the same ethnicity and social class. However, in the case of Rajan's parentage, we realise that tensions are prevalent. Despite the fact that Saha and Neela are both Tamils, surely a great socio-economic divide exists between the two families from the very beginning. Notwithstanding the familial tensions due to the socio-economic mismatch, Rajan is further divided between British Christian education at school and the Hindu religious and cultural ethos at home. At St. Benedicts, he "always ended up being called a pagan and a heathen and was made to kneel outside the classroom for punishment" (When Memory Dies 124). 
All in all, such tensions and divisions can only create an equally divided personality: " [...] when I was at school I felt like a Christian and a "Town Tamil", and when I was at home I felt like a real Jaffna Tamil, and when I went out to play with the boys on our street, I did not feel like a Tamil at all, but a Maradana street urchin" (When Memory Dies 135).

Does this plurality of identity endanger the unification of the nation? Is Rajan a subversive entity? Does his disjunctive multiplicity of being constitute the Other, the unchosen, which disrupts homogenisation? Bhabha elaborates thus on the above issues:

The resistance to acknowledge a cosmopolitanism [...] They refuse to envisage a form of culture that does not ground its beliefs and values in the integrity of the consensual national 'commonality' as the matrix of the cultural authenticity and communal integrity. This nation-centredness with its myriad historical and institutional imperatives-becomes both the cause of cultural panic, and its panacea. ("Anxious Nations and Nervous States 215)

The ambivalence between the marked differences in the occasion of conflict on the one hand, and the disavowal of those very same differences in the name of unified nation on the other hand, can only be explained as a naïve way-out of the complex issues that need to be dealt with. Thus, it is the pronouncent of the word Rajan (a proper noun that is commonly identified as naming a Tamil) that causes the rape of Lali and the psychological breakdown of Rajan. Had it not been uttered, the entire narrative could have taken a different turn. However, at the same time, Rajan is also expected to forget his violent "past" and become one with the Sinhalese and the Muslims in creating a unified nation. What at one moment causes cultural panic, becomes a panacea in the next.

Likewise, in Book Two of When Memory Dies, the trivial mismatches between the Tamils and the Sinhalese are seen to gradually intensify. The horrendous aftermath of the landmark Sinhala-Only Movement of 1956 cannot but aggravate a predicament already sufficiently tense. However, yet again, as if to maintain a sense of hope, the friendship between Rajan and Lal, the later marriage between Rajan and Lali (Lal's sister), and Rajan's adoption of Vijay (the son of Lali and Sena), signal the possibility of harmonious hybridity. Still, as a dream vanishes in wakefulness, the heterogeneous sense of TamilSinhala unity sees a momentary light of day and vanishes in disillusion; Lali, being mistaken for a Tamil, is raped and killed by Sinhalese men, Rajan retires abroad with a 
profound sense of disillusionment and hurt, and finally Vijay, disjointed from any sense of family, is killed by his cousin.

For Vijay, his father, "another ghost, appearing and disappearing in his letters and his gifts and his promises to return" (When Memory Dies 237), can only exist in the realm of the abstract. Unlike both Saha and Rajan, who had a less convoluted family background, Vijay's is one that leaves him with a sense of nihilism. He is genetically mothered by a Sinhalese who is raped and killed by Sinhalese extremists. He is genetically fathered by Sena, a Sinhalese. He is adopted by Rajan, a Tamil. He has Sinhalese and Tamil grandparents. These hybrid roots are ideally expected to make him a fill being. However, at this point, Sivanandan sets down for Vijay, a future that is far from achieving any such positive wholeness.

Somehow, unlike the ghosts of his father, his mother generates memories; "Her memory, not her specter, haunted him now, like an experience, whose meaning he had to find, not later but now, not in the next world but here" (When Memory Dies 237). The trauma of his mother's rape and murder are more immediate to Vijay and come to him as real, raw experience (since he was present at the scene), rather than the distanced ghost of his father. Perhaps, it is such raw memories that Vijay needs to forget. Is this then a mark of escapism? Or, is it a killing of that violent memory of his mother's rape, in order to create false memories which are more comforting?

Vijay, "the only decent thing" (When Memorr Dies 411) may have been killed, yet Sivanandan, on a similar note to the former theorist, neither loses heart over his belief of the possibility of a hybridised "future", nor does he leave his reader with an absolute sense of disappointment. Instead, suggestions are made; suggestions that claim the right of the reader to renarrativise on the ashes of the "past" memory. In fact. "it is this contemporaneity of the "past," mediated by the present that maintains the possibility of a fictitious future (Bhabha, "Anxious Nations and Nervous States" 208). If Vijay, the Sinhalese-born, can feel the pull of non-genetic roots, if Vijay the Sinhalese can give his heart to a Tamil plantation worker, if Vijay the Sinhalese can give up his life for the sake of a Tamil whom he barely knew, then what matters is not his death but rather, that such a one lived.

However melodramatic and contrived the above mesh of incidents may seem, the political comment that Sivanandan makes is of considerable significance. At least, he is unlike the intellectuals that he depicts in his novel. Both Tamil and Sinhalese intellectuals come out in a negative light as they exhibit their ignorance, insensitivity and disinterest in 
relation to the ethnic conflict. They are carried away by their own rhetoric, the masses not understanding a word of what they utter. Thus, Sivanandan, positioning himself as an intellectual who seems to embody a genuine sense of concern for his narrative creations, tries not to fall into the former flock. Further, Sivanandan can even be called an informed writer in the sense that he is aware of the great risks of undertaking the project of the ethnic conflict; writing of a subject of this nature is at the same time to undergo the risk of being accused of partiality. This is perhaps then why, he makes a conscious effort to balance his character portrayal by making use of grey hues than straight black or white. Even if he does level blame on occasion, such blame is distributed amongst them in different degrees. For instance, though Vijay is seen to sympathise with the plight of the Tamil plantation coolies thus revealing the abject conditions in which they live, both Sinhalese and Tamil intellectuals are portrayed as insensitive to the above issues. Moreover, not only are the weaknesses of the PLF revealed but also those of the "Boys"/LTTE. On the one hand, there are Sinhalese extremists in the novel who feel that the Tamils need to be deported to India where they originally belong; on the other hand, there are also characters like Tissa who feel ashamed of the manner in which other Sinhalese wreak havoc in the lives of the Tamils. If some sympathy is shown to the LTTE ("the British took away their past, the Sinhalese took away their future. All they have is the present. And that makes them dangerous" (When Memory Dies 336) ), their practices are portrayed as merely violent and futile:

It [the cyanide pill] was such a symbol of waste, of no-hope, of death as a way of life. It had such a finality about it. Maybe it was alright at the beginning when it symbolised a heroic refusal to inform, at least it implied choice; but now that it had been raised to dogma, belief, ideology, it symbolised the end of choice. And the end of choice was the beginning of terror. (411)

Politics of inclusion and exclusion thus play a significant role in Gilroy's and Sivanandan's texts; the former deliberately includes narratives that had been excluded so far from the mainstream narratives of modernity, while the latter includes the so far excluded subaltern, and finally calls forth the exclusion of his narrative in a bid to fabricate a future different from the violent "past." There is at the same time a claim for coherence and a fear of dissolution. While Gilroy seeks to make the hitherto separate text of the slave cohere with 
the master texts of modernity, Sivanandan aspires to a coherent national text that is unified in its hybridity. However, despite the poignant final scenes of the book, which strike a contrast between the innocence of the bridal scene of Meena with the brutal killing of Vijay, Sivanandan perhaps overdoes his message: Vijay, the Sinhalese-born, fathered/adopted by a Tamil, mothered by a Sinhalese, betrothed to a Tamil estate worker's daughter, dies in the name of a Tamil. Nevertheless, in Yogi taking over, hope seems to linger yet again, since he is depicted from the outset as being capable of rational thinking and sensitivity rather than of mindless violence.

Both Gilroy and Sivanandan thus question in their own terms, "modern homogenous temporality" (Bhabha "Anxious Nations and Nervous States" 209). If Bhabha talks of the nation which is anxious, in that it requires constant reminders of its own presence, and likewise comments on the modern uncertainties of the nation, both Gilroy and Sivanandan perform, what they believe to be a redeeming exercise in including the hitherto excluded Other. If their texts are regarded collectively, one cannot but identify a deep-felt anxiety for the condition of the modern man and woman who constantly undergo the discomfort of an illusory existence. In Para's words, "[s]ociety is changing, too rapidly $[\ldots]$ and people are changing. They look for ambition now, not fulfillment [...] It's a different freedom people want these days, individual, more personal, private even, as though they belonged only to themselves" (When Memory Dies 338). As if in fear for the integrity of their identities, they choose to pretend that they are blind to the conspicuous presence of their identities' Other. Then, can there ever be a full human being who finds her/himself at total ease with her/his identity? Are we or aren't we all going to be "whole again"? (When Memory Dies 411 ). 